Article - Agriculture, Agribusiness and Biotechnology

\title{
Co-production of Proteases and Bioactive Protein Hydrolysates from Bioprocessing of Feather Meal
}

\section{Bernardete da Silva Bernardo ${ }^{1}$}

https://orcid.org/0000-0001-7949-7141

\section{Rodrigo Ferraz Ramos ${ }^{1}$}

https://orcid.org/0000-0002-6414-376X

\section{Kelly Callegaro ${ }^{1}$}

https://orcid.org/0000-0003-2386-5130

\section{Daniel Joner Daroit ${ }^{1^{\star}}$}

https://orcid.org/0000-0001-5469-5766

${ }^{1}$ Federal University of Fronteira Sul (UFFS), Cerro Largo, RS, Brazil.

Received: 2018.11.05; Accepted: 2019.07.08.

*Correspondence: djdaroit@gmail.com; Tel.: +55-55-33594234 (D.J.D.)

\section{HIGHLIGHTS}

- Feather meal (FM) as a low-value organic substrate for microbial conversion.

- Bacterial proteolytic enzymes were produced during FM bioprocessing.

- FM protein hydrolysates displayed in vitro antioxidant and antidiabetic activities.

- Interesting approach to simultaneously obtain added-value products from FM.

\begin{abstract}
Feather meal conversion through submerged cultivations with Bacillus strains (CL33A, CL14) yielded proteases and protein hydrolysates. After 4-day (CL33A) and 10-day (CL14) cultivations, protease activities reached $461 \mathrm{U} / \mathrm{mL}$; hydrolysates presented antioxidant (radicals-scavenging, 57-77\%; $\mathrm{Fe}^{2+}$-chelation, 14-28\%; $\mathrm{Fe}^{3+}$-reduction) and antidiabetic (dipeptidyl peptidase-IV inhibition, 49-52\%) potentials. The obtained bioproducts present prospective commercial/industrial applications.
\end{abstract}

Keywords: Bacillus; bioprocess; enzyme; antioxidant; antidiabetic.

\section{INTRODUCTION}

Environmental and economic issues are essential aspects related to the management of organic wastes and by-products derived from agro-industrial activities. Recognition that such materials might be converted into multiple products through suitable methods, 
representing an additional source of profit, established a major foundation of biorefineries within the principles of sustainable development $[1,2]$.

Feathers, abundantly generated from poultry processing for meat production, are mainly constituted of keratins, fibrous and refractory proteins corresponding to $90 \%$ of the feather dry weight [3]. The recalcitrance of feathers, resulting from the compact packing and stabilization of keratin polypeptides, might be a drawback for its recycling and destination [4]. Hydrothermal conversion of feathers into feather meal (FM) is a major technological approach for feathers reclamation. FM is particularly intended for animal feed; however, such application is restricted due to its poor digestibility and low nutritional value $[5,6]$.

Innovative processes could lead to further valorization of FM. In this sense, microbial technologies provide a vast array of eco-friendly possibilities to obtain valuable products from renewable biomass [7]. Bioconversion of FM by keratinolytic microorganisms might be exploited to obtain microbial enzymes with biotechnological significance, specially proteases and keratinases, and also microbial biomass and protein hydrolysates. FM presents a higher accessibility than raw feathers as substrates for microbial action, thus potentially hastening the processes intended to obtain such bioproducts $[5,8]$.

Production of hydrolysates from protein-rich wastes and by-products is increasingly focused, since these hydrolysates might display biological activities, such as antioxidant and antidiabetic properties, with potential relevance for food, feed, and pharmaceutical industries $[9,10]$. Nevertheless, the bioactivities of feather and FM hydrolysates obtained through microbial conversion were only recently described, representing a promising field for research and development [11].

Therefore, the aim of this study was to utilize two feather-degrading bacteria for FM bioprocessing, as a strategy to obtain added-value products. From the proteinaceous composition of FM and the proteolytic potentials of the bacterial strains, it is hypothesized that the simultaneous production of bacterial proteases and bioactive feather meal hydrolysates $(\mathrm{FMH})$ might be feasible.

\section{MATERIAL AND METHODS}

The previously isolated proteolytic bacteria, Bacillus sp. CL33A and Bacillus sp. CL14, were employed for FM bioconversion. Bacterial suspensions, used to inoculate feather meal broth $(\mathrm{FMB})$, were prepared in saline $(8.5 \mathrm{~g} / \mathrm{L} \mathrm{NaCl})$. FMB consisted of $(\mathrm{g} / \mathrm{L}): \mathrm{K}_{2} \mathrm{HPO}_{4}, 0.3$; $\mathrm{KH}_{2} \mathrm{PO}_{4}, 0.4 ; \mathrm{NaCl} 0.5$; and FM, 10.0 (Kabsa S.A., Brazil). Initial pH of FMB was adjusted to 7.5. Erlenmeyers $(250 \mathrm{~mL}$ ) containing $50 \mathrm{~mL}$ of $\mathrm{FMB}$ were inoculated with $1 \mathrm{~mL}$ of bacterial suspension, and cultivations were performed $30{ }^{\circ} \mathrm{C}, 125 \mathrm{rpm}$. At specific intervals, cultivations were filtered through filter paper, and the residual FM was determined gravimetrically after drying to constant weight $\left(60^{\circ} \mathrm{C}\right)$. Filtrates were centrifuged $(10,000 \mathrm{~g}$, $10 \mathrm{~min}$ ) and supernatants were collected.

Protease production by the keratinolytic strains was evaluated on culture supernatants. Azocasein was used as substrate in assays performed for $30 \mathrm{~min}$, at $55^{\circ} \mathrm{C}, \mathrm{pH} 8.0$. One activity unit $(U)$ was defined as the amount of enzyme resulting in an increase of 0.01 absorbance units at $420 \mathrm{~nm}$ [8].

Culture supernatants were heated $\left(100{ }^{\circ} \mathrm{C}, 10 \mathrm{~min}\right)$ to inactivate microbial enzymes, and henceforth referred to FMHs. Soluble protein of FMHs was determined by the Folin-phenol method.

Antioxidant activities of FMHs were assessed through four in vitro methods. Scavenging of the 2,2-diphenyl-1-picrylhydrazyl (DPPH) radical was evaluated by adding FMH (1 mL) to $3.9 \mathrm{~mL}$ of DPPH solution ( $60 \mu \mathrm{M}$, prepared in methanol). Reactions were carried out for 60 min in the absence of light, at room temperature, and DPPH scavenging was assessed at $517 \mathrm{~nm}$ [12]. Distilled water was used as control. DPPH scavenging was expressed as: Scavenging $(\%)=\left[1-\left(A_{s} / B_{c}\right)\right] \times 100$, where $A_{s}$ and $B_{c}$ represents the absorbance with $F M H$ or with distilled water, respectively.

Scavenging of the 2,2'-azino-bis-(3-ethylbenzothiazoline)-6-sulfonic acid (ABTS) radical was also assessed [13]. ABTS radical solution was diluted with phosphate-buffered saline $(5 \mathrm{mM}, \mathrm{pH} 7.4)$ to reach $0.70 \pm 0.02$ absorbance units at $734 \mathrm{~nm}$. A $10 \mu \mathrm{L}$ aliquot of 
FMH was added to $1 \mathrm{~mL}$ of ABTS radical solution and, after $6 \mathrm{~min}$, the absorbance was measured at $734 \mathrm{~nm}$. Controls were performed with distilled water. ABTS radical scavenging was expressed as: Scavenging $(\%)=\left[1-\left(A_{s} / B_{c}\right)\right] \times 100$, where $A_{s}$ and $B_{c}$ indicates absorbance with $\mathrm{FMH}$ or distilled water, respectively.

$\mathrm{Fe}^{2+}$-chelating ability of $\mathrm{FMHs}$ was assessed by adding $100 \mu \mathrm{L} \mathrm{FMH}$ to $3.7 \mathrm{~mL}$ of distilled water, $100 \mu \mathrm{L}$ of $2 \mathrm{mM} \mathrm{FeSO}_{4}$ and $200 \mu \mathrm{L}$ of $5 \mathrm{mM}$ ferrozine (3-(2-pyridyl)-5,6-bis(4-phenyl-sulfonic acid)-1,2,4-triazine). After $10 \mathrm{~min}$, absorbances were measured at $562 \mathrm{~nm}$ [14]. Control assays were performed using $100 \mu \mathrm{L}$ of distilled water. Results were obtained as: Fe ${ }^{2+}$-chelating activity $(\%)=\left[1-\left(A_{s} / B_{c}\right)\right] \times 100$, where $A_{s}$ and $B_{c}$ represents the absorbance with $\mathrm{FMH}$ or with distilled water, respectively.

Reducing power of FMHs was evaluated by mixing $1 \mathrm{~mL}$ of FMH with $2.5 \mathrm{~mL}$ of $200 \mathrm{mM}$ phosphate buffer ( $\mathrm{pH} \mathrm{6.6)}$ and $2.5 \mathrm{~mL}$ of $10 \mathrm{~g} / \mathrm{L}$ potassium ferricyanide. After incubation at $50{ }^{\circ} \mathrm{C}$ for $30 \mathrm{~min}, 2.5 \mathrm{~mL}$ of $100 \mathrm{~g} / \mathrm{L}$ trichloroacetic acid were added. This mixture was centrifuged (3,000 g, $10 \mathrm{~min})$, and $2.5 \mathrm{~mL}$ of the collected supernatant were mixed with 2.5 $\mathrm{mL}$ distilled water and $500 \mu \mathrm{L}$ of $1 \mathrm{~g} / \mathrm{L} \mathrm{FeCl}_{3}$. Controls were performed using $1 \mathrm{~mL}$ of distilled water instead of $\mathrm{FMH}$. Absorbances were measured at $700 \mathrm{~nm}$, and results expressed as absorbance units at $700 \mathrm{~nm}\left(\mathrm{~A}_{700}\right)$, as described elsewhere [14].

In vitro antidiabetic capacity of FMH was evaluated by the ability to inhibit dipeptidyl peptidase-IV (DPP IV) activity towards Gly-Pro-p-nitroanilide [15]. Briefly, $25 \mu \mathrm{L}$ of FMH was mixed with $25 \mu \mathrm{L}$ of $2.0 \mathrm{mM}$ Gly-Pro-p-nitroanilide (prepared in $50 \mathrm{mM}$ Tris-HCl buffer, $\mathrm{pH}$ 7.6), and this mixture was heated at $37^{\circ} \mathrm{C}$ for $10 \mathrm{~min}$. Reactions were initiated by adding 50 $\mu \mathrm{L}$ of DPP IV $\left(0.01 \mathrm{U} / \mathrm{mL}\right.$, prepared in Tris- $\mathrm{HCl}$ buffer) and, after incubation $\left(37^{\circ} \mathrm{C}, 60 \mathrm{~min}\right)$, reactions were finished with $100 \mu \mathrm{L}$ of $1 \mathrm{M}$ acetate buffer $(\mathrm{pH} 4.0)$. Absorbance was measured at $405 \mathrm{~nm}$. DPP IV inhibition were calculated as: Inhibition $(\%)=\{1-[(A-B) /(C-$ D)] $\times 100$, where $A$ is the absorbance in reactions containing DPP IV, substrate and $\mathrm{FMH}$; $B$ is the absorbance in reactions containing substrate, $\mathrm{FMH}$, and buffer; $\mathrm{C}$ is the absorbance in reactions containing DPP IV, substrate, and distilled water; $D$ is the absorbance in reactions containing substrate, with buffer and distilled water instead of DPP IV and $\mathrm{FMH}$, respectively.

All described assays were conducted in triplicates. Data were presented as average values \pm standard deviations, which were subjected to analysis of variance, and the means were compared by Tukey's test at $95 \%$ confidence level.

\section{RESULTS AND DISCUSSION}

Bacterial conversion of FM was evaluated by the residual mass of FM during cultivations. Bacillus sp. CL33A degraded $62 \%$ and $92 \%$ of FM after 3 and 7 days of cultivation, respectively (Fig. 1a), whereas $76 \%$ and $98 \%$ of FM was degraded by Bacillus sp. CL14 after 7 and 13 days (Fig. 1b). Son et al. [16] reported $96 \%$ of FM degradation by $B$. pumilis F3-4 after 7 days of submerged cultivations in FM medium. In an investigation with Bacillus sp. P7, $87 \%$ of FM was degraded after 4 days [8], and B. subtilis $1270, B$. subtilis 1273 , and $B$. licheniformis 1274 degraded $63 \%, 70 \%$, and $76 \%$ of FM after 7 days [17].

Increased protease production by CL33A was detected after four days on FMB (461 $\mathrm{U} / \mathrm{mL}$; Fig. 1a). Proteolytic activity was observed to decrease after day 4, possibly due to product negative feedback or autolysis [18]. Higher protease production by CL14 (462 U/mL; Fig. 1b) was similar to that detected for CL33A; however, this was observed only after 10 days of cultivation with Bacillus sp. CL14 (Fig. 1b). Production of keratinolytic proteases by 5 bacterial strains peaked after 3-6 days of cultivation on FMB [19], 4-day cultivations resulted in higher protease production by five Bacillus strains [20], and increased enzyme production was achieved by $B$. subtilis FDS15 in FM medium after 3 days [21]. 


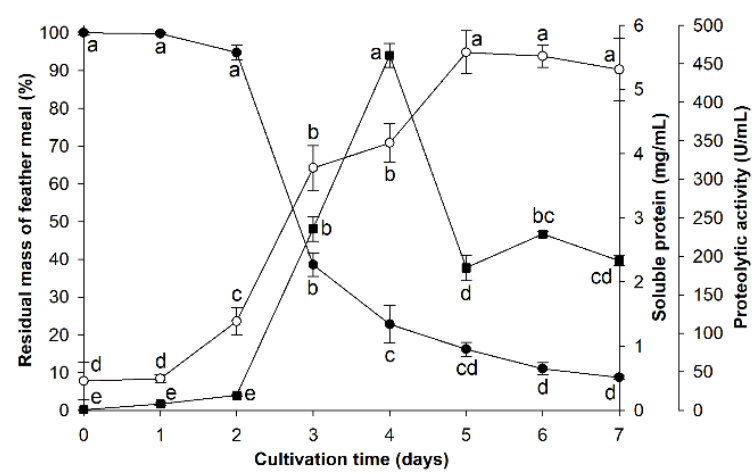

(a)

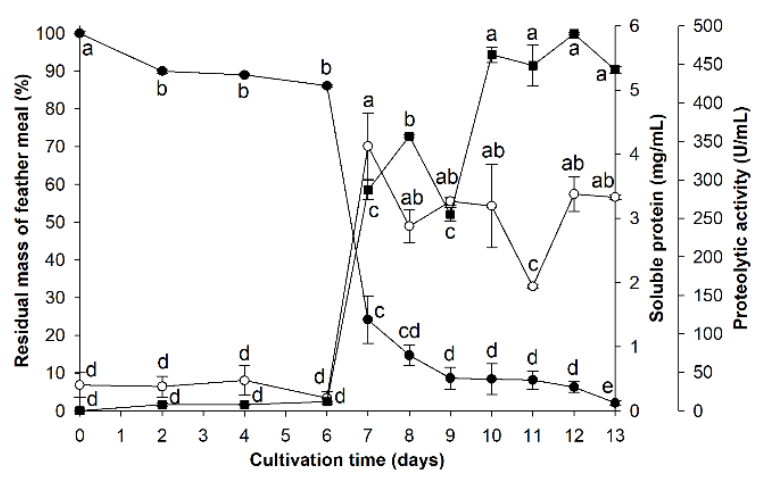

(b)

Figure 1. Feather meal degradation $(\bullet, \%)$, protease production $(\bullet, \mathrm{U} / \mathrm{mL})$, and soluble protein concentration $(\circ, \mathrm{mg} / \mathrm{mL})$ during submerged cultivations with Bacillus sp. CL33A (a) and Bacillus sp. CL14 (b) on feather meal broth. Data points are means \pm standard deviation of experiments performed in triplicates. Different lowercase letters indicate significant differences $(P<0.05)$ within each evaluated parameter.

Considering that FM was the only organic substrate in $F M B$, and that $F M$ is composed mainly of proteins (keratins), production of proteolytic enzymes is required to hydrolyze FM into absorbable peptides and amino acids that will sustain bacterial growth and energy production [5]. Beyond the microbial perspective, proteases from Bacillus are important commercial biocatalysts, employed by the detergent, food, feed, leather, pharmaceutical, and other industries [22]. Hence, the utilization of alternative low-price substrates, such as $\mathrm{FM}$, is increasingly acknowledged as a strategy to diminish the costs of enzyme production [5].

Degradation of FM resulted, as expected, in increases on soluble protein contents assessed in culture supernatants [20]. For Bacillus sp. CL33A, soluble protein peaked at 5 days of cultivation $(5.5 \mathrm{mg} / \mathrm{mL})$, with similar values at increasing cultivation times (Fig. 1a). Soluble protein during cultivations with CL14 peaked at day $7(4.1 \mathrm{mg} / \mathrm{mL})$, and variations on soluble protein were observed afterwards (Fig. 1b). The buildup of soluble proteins during cultivations indicate its release in higher amounts than needed for the bacteria, and a decreased content at longer cultivations suggests the decreased availability of FM.

Cultivations with three Bacillus strains on FM medium resulted in soluble protein contents of 3.9-4.4 mg/mL after 7 days [17], whereas growth of $B$. pumilis F3-4 in FM-based medium for 7 days resulted in soluble protein concentration of $1.8 \mathrm{mg} / \mathrm{mL}$ [16]. The increased time required by Bacillus sp. CL14 for effective FM degradation, resulting from a lag period for increased protease production, with noticeable effects on soluble protein release, indicates the higher keratinolytic efficiency of Bacillus sp. CL33A [19].

Although FM and feathers are employed as substrates for keratinolytic bacteria, the main purpose is to produce proteolytic enzymes [5]. More recent studies also draw attention to applications of protein hydrolysates resulting from the bioconversion of keratinous materials. These are claimed as nitrogen-rich fertilizers and ingredients in animal feed $[6,23]$. An additional innovative approach for biomass valorization resides on prospecting the bioactivities of microbially-produced keratin hydrolysates, which depend on peptides and amino acids released upon hydrolysis [11,24].

The antioxidant and antidiabetic activities of $\mathrm{FMHs}$ were then evaluated in vitro. $\mathrm{FMHs}$ produced by Bacillus sp. CL33A and Bacillus sp. CL14 were able to scavenge the DPPH and ABTS radicals (Fig. 2). For strain CL33A, FMH obtained after 4 days of cultivation scavenged $63 \%$ and $76 \%$ of DPPH and ABTS radicals, respectively, and these values were maintained for FMHs recovered at longer cultivation periods (Fig. 2a). Maximal DPPH scavenging of FMHs produced by CL14 was observed after 7 days $(61 \%)$; the same FMH displayed ABTS-radical scavenging of $67 \%$, but FMHs obtained after 12 days were able to scavenge $85 \%$ of the ABTS radical (Fig. $2 \mathrm{~b}$ ). These results indicate the ability of FMHs to transfer hydrogen and electrons to DPPH and ABTS radicals, respectively, stabilizing them [25]. 


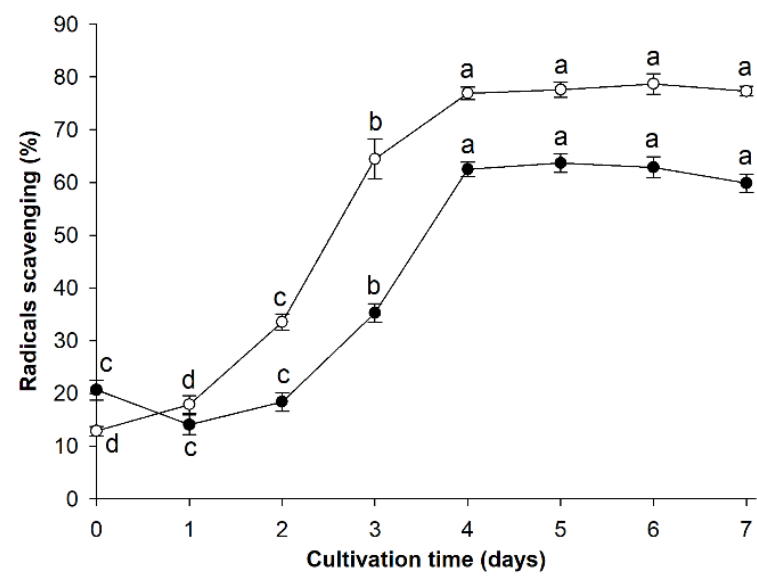

(a)

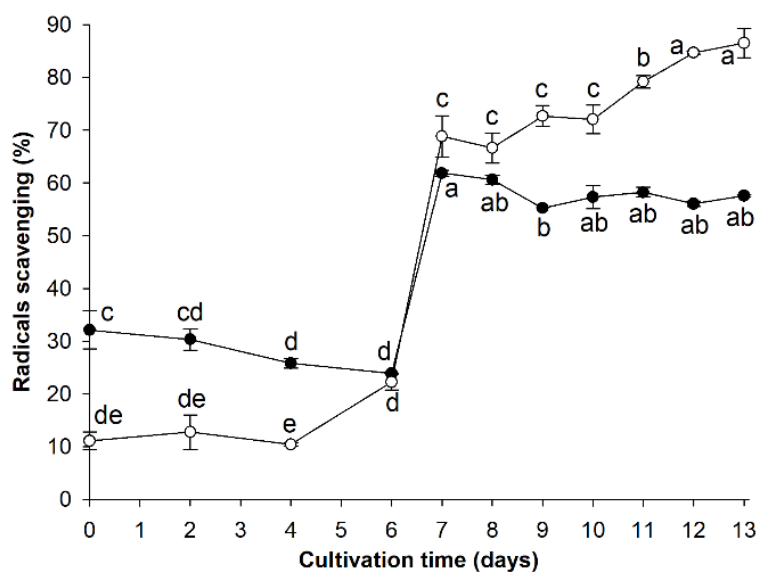

(b)

Figure 2. Antioxidant potential, as assessed through the scavenging of DPPH radicals $(\bullet, \%)$ and ABTS radicals (०, \%), of feather meal hydrolysates produced by Bacillus sp. CL33A (a) and Bacillus sp. CL14 (b) during submerged cultivations on feather meal broth. Data points are means \pm standard deviation of experiments performed in triplicates. Different lowercase letters indicate significant differences $(P<0.05)$ within each evaluated parameter.

Bacillus sp. P45 was employed for FM bioconversion, and hydrolysates showed radical-scavenging abilities [26]. The scavenging of DPPH (68\%) and ABTS (75\%) was reported for feather hydrolysates produced by Chryseobacterium sp. kr6 [27]. Protein hydrolysates with radical-scavenging abilities were also obtained from fermentation of fish visceral waste and fish head waste by lactic acid bacteria [28,29]. Hydrolysates of squid pen waste and shrimp shell waste powders produced by Serratia sp. TKU016 exhibited higher DPPH-scavenging after 3 days (50\%) and 2 days (76\%) of cultivation, respectively [30].

FMHs were observed to chelate $\mathrm{Fe}^{2+}$ (Fig. 3). This metal ion is involved in the production of highly oxidant hydroxyl radicals that leads to radical chain reactions [31]. The chelating ability of hydrolysates produced by strain CL33A reached $28 \%$ and $47 \%$ after 4 and 7 days of cultivation, respectively (Fig. 3a), whereas $14 \%$ and $41 \%$ of $\mathrm{Fe}^{2+}$ ions were chelated by FMHs obtained after 10 and 13 days with CL14 (Fig. 3b). FMHs were also assessed for their capability to donate electrons to $\mathrm{Fe}^{3+}$, reducing it to $\mathrm{Fe}^{2+}$ [31]. Increased reducing power was measured for FMHs obtained at 4-6 days of cultivation with CL33A (Fig. 3a). Similar reducing power $\left(0.42-0.46 A_{700}\right)$ was observed for $F M H s$ produced by strain CL14 after 7-10 days; however, superior reducing power $\left(0.58 A_{700}\right)$ was detected after 11 days of cultivation (Fig. 3b).

Protein hydrolysates obtained by submerged cultivations with Serratia marcescens, Pseudomonas aeruginosa, or Bacillus pumilus on shrimp shell waste displayed reducing power, and hydrolysates with higher activity were produced by S. marcescens [32]. Salmon viscera hydrolysates, produced through lactic acid fermentation, displayed slight increases on $\mathrm{Fe}^{2+}$-chelation after $6 \mathrm{~h}$ of cultivation, which then decreased at longer periods (up to 8 days), including values lower than the starting material. Also, microbial hydrolysis was detrimental to the reducing power of salmon viscera [33].

Feather hydrolysates produced by $B$. pumilus $A 1$ displayed $\mathrm{Fe}^{2+}$-chelating ability and reducing power [34,35]. However, feather hydrolysates obtained with Chryseobacterium sp. kr6 exhibited reducing power, but not $\mathrm{Fe}^{2+}$-chelation [36]. Reducing power and radical scavenging were also displayed by feather hydrolysates produced by Bacillus sp. MPTK6 [37], and Kocuria rhizophila p3-3 [38]. Such potentials were also verified for hydrolysates of delimed tannery fleshings obtained by 4-day cultivations with Enterococcus faecium NCIM5335 [39], for shrimp shell waste hydrolysates produced by $P$. aeruginosa A2 [40]. In addition, multiple antioxidant activities, such as radical scavenging, reducing power and the ability to chelate ferrous ions, were demonstrated for fish (Acanthogobius hasta) processing 
by-product protein hydrolysates, produced through solid-state fermentations with Aspergillus oryzae [10].

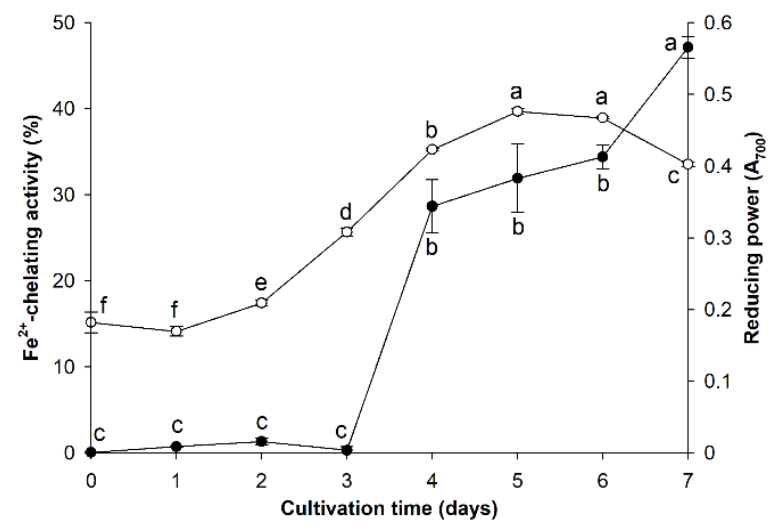

(a)

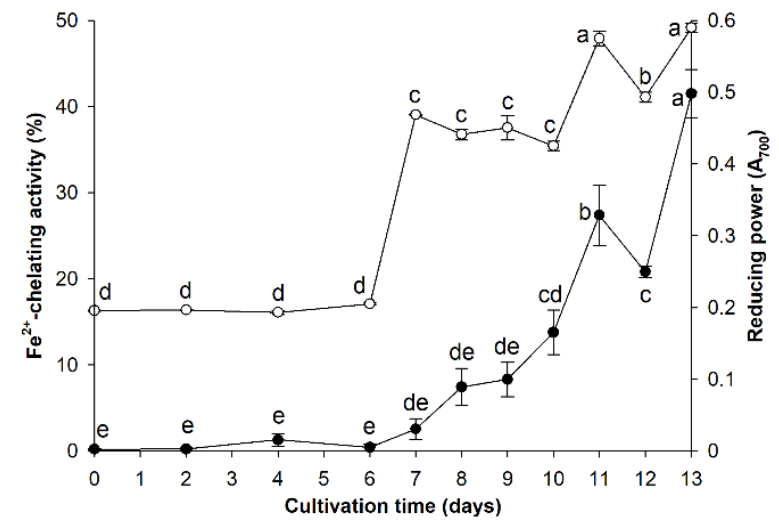

(b)

Figure 3. Antioxidant potential, as assessed through reducing power $\left(\circ, \mathrm{A}_{700}\right)$ and $\mathrm{Fe}^{2+}$-chelating ability $(\bullet, \%)$, of feather meal hydrolysates produced by Bacillus sp. CL33A (a) and Bacillus sp. CL14 (b) during submerged cultivations on feather meal broth. Data points are means \pm standard deviation of experiments performed in triplicates. Different lowercase letters indicate significant differences $(P<0.05)$ within each evaluated parameter.

The antidiabetic activity of protein hydrolysates is usually evaluated, in vitro, by the inhibition of DPP IV, since this enzyme is responsible for the degradation of insulinotropic incretin hormones. Therefore, protein hydrolysates might act as natural DPP IV-inhibitors, potentially contributing to glycemic control in type 2 diabetes [41]. The inhibitory activity of FMHs produced by strain CL33A peaked after 3 days of cultivation (58\%), with lower percentages of inhibition at increasing cultivation times (42-48\%; Fig. 4a). Considering strain CL14, FMHs obtained at days 7-9 inhibited DPP IV by 33-39\%; nevertheless, $\mathrm{FMHs}$ produced after 10 and 12 days of cultivation exhibited $52 \%$ and $55 \%$ of DPP IV inhibition (Fig. $4 b)$.

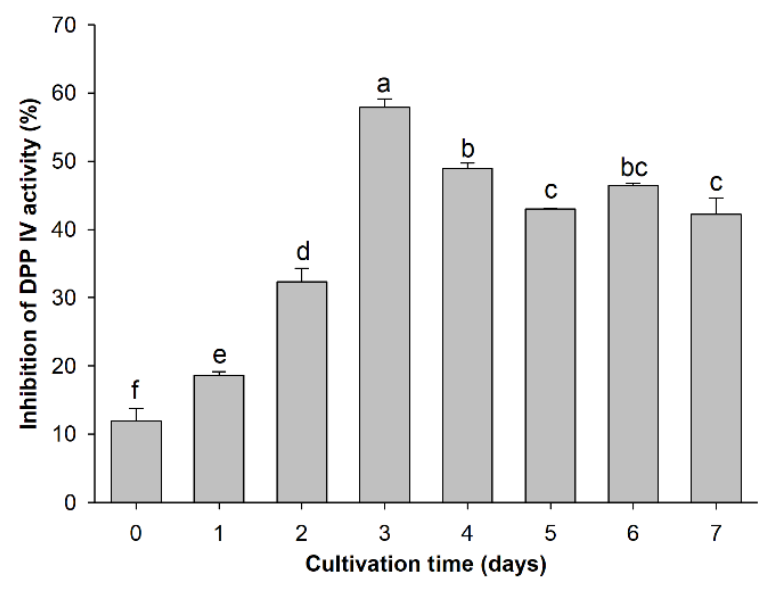

(a)

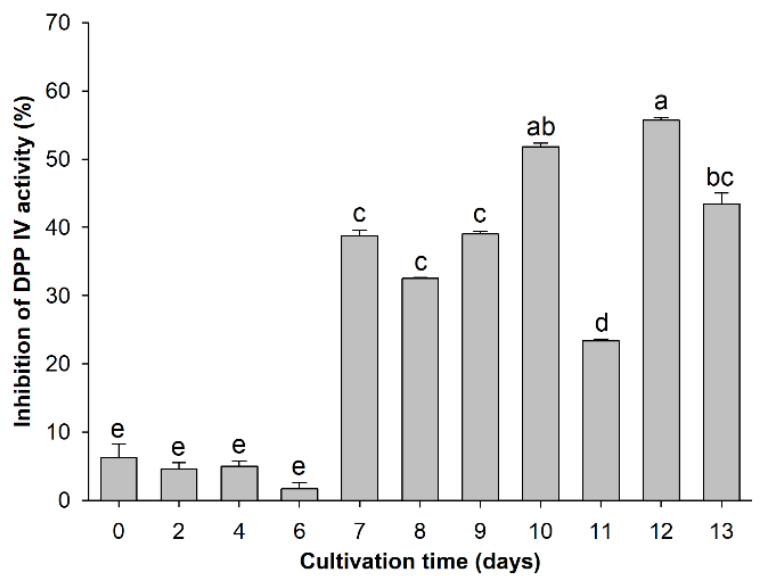

(b)

Figure 4. Inhibition of DPP IV activity (\%) by feather meal hydrolysates produced by Bacillus sp. CL33A (a) and Bacillus sp. CL14 (b) during submerged cultivations on feather meal broth. Each column represents the mean \pm standard deviation of experiments performed in triplicates. Different lowercase letters indicate significant differences $(P<0.05)$.

Current research is devoted to describe the antidiabetic capacity of protein hydrolysates obtained from industrial by-products. Feathers bioprocessing by Chryseobacterium sp. kr6 resulted in hydrolysates that inhibited DPP IV activity by 43-45\% [27]. DPP IV inhibition was 
also reported for enzymatic hydrolysates of salmon skin and trimmings [42], cuttlefish viscera [43], and brewers' spent grain protein-enriched isolate [44].

In conclusion, FM was successfully employed for the co-production of proteolytic enzymes and bioactive protein hydrolysates by Bacillus sp. CL33A and Bacillus sp. CL14. The former strain was more efficient for FM bioprocessing. From the culture conditions employed, 4-day cultivations with Bacillus sp. CL33A on FMB are regarded as appropriate aiming to obtain proteases and bioactive hydrolysates.

Bacterial proteases might be of significance for biocatalytic processes, deserving further investigations, especially regarding the production of bioactive hydrolysates from food and non-food proteins. The antioxidant properties of FMHs are relevant considering the deleterious action of free radicals and prooxidant metals on biological systems, and also food and feed products. The ability of FMHs to inhibit DPP IV activity indicates the possibility of obtaining antidiabetic peptides from an abundant and low-cost biomass. From the current and limited uses of FM, bioprocessing is a suitable approach for its valorization.

Funding: This research was funded by Conselho Nacional de Desenvolvimento Científico e Tecnológico (CNPq), Grant number 402631/2016-1.

Conflicts of Interest: The authors declare no conflict of interest. The funders had no role in the design of the study; in the collection, analyses, or interpretation of data; in the writing of the manuscript, or in the decision to publish the results.

\section{REFERENCES}

1. Clark JH, Luque R, Matharu AS. Green chemistry, biofuels, and biorefinery. Annu Rev Chem Biomol Eng. 2012;3:183-207.

2. Kiran EU, Trzcinski AP, Ng WJ, Liu Y. Enzyme production from food wastes using a biorefinery concept. Waste Biomass Valor. 2014;5:903-17.

3. Sharma S, Gupta A. Sustainable management of keratin waste biomass: applications and future perspectives. Braz Arch Biol Technol. 2016;59:e16150684.

4. Lasekan A, Abu Bakar F, Hashim D. Potential of chicken by-products as sources of useful biological resources. Waste Manag. 2013;33:552-65.

5. Verma A, Singh H, Anwar S, Chattopadhyay A, Tiwari KK, Kaur S, et al. Microbial keratinases: industrial enzymes with waste management potential. Crit Rev Biotechnol. 2017;37:476-91.

6. Maciel JL, Werlang PO, Daroit DJ, Brandelli A. Characterization of protein-rich hydrolysates produced through microbial conversion of waste feathers. Waste Biomass Valor. 2017;8:1177-86.

7. Pleissner D, Venus J. Utilization of protein-rich residues in biotechnological processes. Appl Microbiol Biotechnol. 2016;100:2133-40.

8. Corrêa APF, Daroit DJ, Brandelli A. Characterization of a keratinase produced by Bacillus sp. P7 isolated from an Amazonian environment. Int Biodeterior Biodegrad. 2010;64:1-6.

9. Toldrá F, Mora L, Reig M. New insights into meat by-product utilization. Meat Sci. 2016;120:54-9.

10. Fang Y, Wang S, Liu S, Lu M, Jiao Y, Chen G, et al. Solid-state fermentation of Acanthogobius hasta processing by-products for the production of antioxidant protein hydrolysates with Aspergillus oryzae. Braz Arch Biol Technol. 2015;58:343-52.

11. Sinkiewicz I, Staroszczyk H, Śliwińska A. Solubilization of keratins and functional properties of their isolates and hydrolysates. J Food Biochem. 2018;42:e12494.

12. Brand-Williams W, Cuvelier ME, Berset C. Use of a free radical method to evaluate antioxidant activity. LWT-Food Sci Technol. 1995;28:25-30.

13. Re R, Pellegrini N, Proteggente A, Pannala A, Yang M, Rice-Evans C. Antioxidant activity applying an improved ABTS radical cation decolorization assay. Free Radic Biol Med. 1999;26:1231-7.

14. Chang $\mathrm{C}-\mathrm{Y}, \mathrm{Wu} \mathrm{K}-\mathrm{C}$, Chiang S-H. Antioxidant properties and protein compositions of porcine haemoglobin hydrolysates. Food Chem. 2007;100:1537-43. 
15. Kojima K, Hama T, Kato T, Nagatsu T. Rapid chromatographic purification of dipeptidyl peptidase IV in human submaxillary gland. J Chromatogr. 1980;189:233-40.

16. Son HJ, Park HC, Kim HS, Lee CY. Nutritional regulation of keratinolytic activity in Bacillus pumilis. Biotechnol Lett. 2008;30:461-5.

17. Mazotto AM, Coelho RRR, Cedrola SML, Lima MF, Couri S, Souza EP, et al. Keratinase production by three Bacillus spp. using feather meal and whole feather as substrate in a submerged fermentation. Enzyme Res. 2011;2011:523780.

18. Ghasemi Y, Shahbazi M, Rasoul-Amini S, Kargar M, Safari A, Kazemi A, et al. Identification and characterization of feather-degrading bacteria from keratin-rich wastes. Ann Microbiol. 2012;62:737-44.

19. Riffel A, Brandelli A. Keratinolytic bacteria isolated from feather waste. Braz J Microbiol. 2006;37:395-9.

20. Queiroga C, Pintado ME, Malcata FX. Potential use of wool-associated Bacillus species for biodegradation of keratinous materials. Int Biodeterior Biodegrad. 2012;70:60-5.

21. Sekar V, Kannan M, Ganesan R, Dheeba B, Sivakumar N, Kannan K. Isolation and screening of keratinolytic bacteria from feather dumping soil in and around Cuddalore and Villupuram, Tamil Nadu. Proc Natl Acad Sci, India, Sect B Biol Sci. 2016;86:567-75.

22. Contesini FJ, Melo RR, Sato HH. An overview of Bacillus proteases: from production to application. Crit Rev Biotechnol. 2018;38:321-34.

23. Paul T, Das A, Mandal A, Halder SK, DasMohapatra PK, Pati BR, et al. Valorization of chicken feather waste for concomitant production of keratinase, oligopeptides and essential amino acids under submerged fermentation by Paenibacillus woosongensis TKB2. Waste Biomass Valor. 2014;5:575-84.

24. Lemes AC, Sala L, Ores JC, Braga ARC, Egea MB, Fernandes KF. A review of the latest advances in encrypted bioactive peptides from protein-rich waste. Int $\mathrm{J}$ Mol Sci. 2016;17:950.

25. Sbroggio MF, Montilha MS, Figueiredo VRG, Georgetti SR, Kurozawa LE. Influence of the degree of hydrolysis and type of enzyme on antioxidant activity of okara protein hydrolysates. Food Sci Technol (Campinas). 2016;36:375-81.

26. Lemes AC, Álvares GT, Egea MB, Brandelli A, Kalil SJ. Simultaneous production of proteases and antioxidant compounds from agro-industrial by-products. Bioresour Technol. 2016;222:210-6.

27. Fontoura R, Daroit DJ, Corrêa APF, Meira SMM, Mosquera M, Brandelli A. Production of feather hydrolysates with antioxidant, angiotensin-I converting enzyme- and dipeptidyl peptidase-IV-inhibitory activities. New Biotechnol. 2014;31:506-13.

28. Rai AK, Jini R, Swapna HC, Sachindra NM, Bhaskar N, Baskaran V. Application of native lactic acid bacteria (LAB) for fermentative recovery of lipids and proteins from fish processing wastes: bioactivities of fermentation products. J Aquat Food Prod Technol. $2011 ; 20: 32-44$.

29. Ruthu N, Murthy PS, Rai AK, Bhaskar N. Fermentative recovery of lipids and proteins from freshwater fish head waste with reference to antimicrobial and antioxidant properties of protein hydrolysate. J Food Sci Technol. 2014;51:1884-92.

30. Wang S-L, Chang T-J, Liang T-W. Conversion and degradation of shellfish wastes by Serratia sp. TKU016 fermentation for the production of enzymes and bioactive materials. Biodegradation. 2010:21:321-33.

31. Xie Z, Huang J, Xu X, Jin Z. Antioxidant activity of peptides isolated from alfalfa leaf protein hydrolysate. Food Chem. 2008;111:370-6.

32. Sedaghat F, Yousefzadi M, Toiserkani H, Najafipour S. Chitin from Penaeus merguiensis via microbial fermentation processing and antioxidant activity. Int $\mathrm{J}$ Biol Macromol. 2016;82:279-83.

33. Rajendran SRCK, Mohan A, Khiari Z, Udenigwe CC, Mason B. Yield, physicochemical, and antioxidant properties of Atlantic salmon visceral hydrolysate: Comparison of lactic acid bacterial fermentation with Flavourzyme proteolysis and formic acid treatment. J Food Process Preserv. 2018;42:e13620. 
34. Fakhfakh N, Ktari N, Haddar A, Mnif IH, Dahmen I, Nasri M. Total solubilisation of the chicken feathers by fermentation with a keratinolytic bacterium, Bacillus pumilus $\mathrm{A} 1$, and the production of protein hydrolysate with high antioxidative activity. Process Biochem. 2011;46:1731-7.

35. Fakhfakh N, Gargouri M, Dahmen I, Sellami-Kamoun A, El Feki A, Nasri M. Improvement of antioxidant potential in rats consuming feathers protein hydrolysate obtained by fermentation of the keratinolytic bacterium, Bacillus pumilus A1. Afr J Biotechnol. 2012;11:938-49.

36. Fontoura R, Daroit DJ, Corrêa APF, Moresco KS, Santi L, Beys-Da-Silva WO, et al. Characterization of a novel antioxidant peptide from feather keratin hydrolysates. New Biotechnol. 2019;49:71-6.

37. Kumar DJM, Priya P, Balasundari SN, Devi GSDN, Rebecca AIN, Kalaichelvan PT. Production and optimization of feather protein hydrolysate from Bacillus sp. MPTK6 and its antioxidant potential. Middle-East J Sci Res. 2012;11:900-7.

38. Łaba W, Żarowska B, Chorążyk D, Pudło A, Piegza M, Kancelista A, et al. New keratinolytic bacteria in valorization of chicken feather waste. AMB Express. 2018;8:9.

39. Balakrishnan B, Prasad B, Rai AK, Velappan SP, Subbanna MN, Narayan B. In vitro antioxidant and antibacterial properties of hydrolysed proteins of delimed tannery fleshings: comparison of acid hydrolysis and fermentation methods. Biodegradation. 2011;22:287-95.

40. Ghorbel-Bellaaj O, Jridi M, Ben Khaled H, Jellouli K, Nasri M. Bioconversion of shrimp shell waste for the production of antioxidant and chitosan used as fruit juice clarifier. Int J Food Sci Technol. 2012;47:1835-41.

41. Power $O$, Nongonierma $A B$, Jakeman $P$, Fitzgerald RJ. Food protein hydrolysates as a source of dipeptidyl peptidase IV inhibitory peptides for the management of type 2 diabetes. Proc Nutr Soc. 2014;73:34-46.

42. Harnedy PA, Parthsarathy V, Mclaughlin CM, O'Keeffe MB, Allsopp PJ, Mcsorley EM, et al. Atlantic salmon (Salmo salar) co-product-derived protein hydrolysates: A source of antidiabetic peptides. Food Res Int. 2018;106:598-606.

43. Cudennec B, Balti R, Ravallec, R, Caron J, Bougatef A, Dhulster P, et al. In vitro evidence for gut hormone stimulation release and dipeptidyl-peptidase IV inhibitory activity of protein hydrolysate obtained from cuttlefish (Sepia officinalis) viscera. Food Res Int. 2015;78:238-45.

44. Connolly A, Piggott CO, FitzGerald RJ. In vitro a-glucosidase, angiotensin converting enzyme and dipeptidyl peptidase-IV inhibitory properties of brewers' spent grain protein hydrolysates. Food Res Int. 2014;56:100-7.

(C) 2018 by the authors. Submitted for possible open access publication under the terms and conditions of the Creative Commons Attribution (CC BY NC) license (https://creativecommons.org/licenses/by-nc/4.0/). 